\title{
GH overexpression causes muscle hypertrophy independent from local IGF-I in a zebrafish transgenic model
}

\author{
Rafael Y. Kuradomi • Márcio A. Figueiredo • Carlos F. C. Lanes • \\ Carlos E. da Rosa • Daniela V. Almeida • Rodrigo Maggioni · \\ Maeli D. P. Silva $\cdot$ Luis F. Marins
}

Received: 3 November 2009/Accepted: 7 July 2010/Published online: 17 July 2010

(C) Springer Science+Business Media B.V. 2010

\begin{abstract}
The aim of the present study was to analyse the morphology of white skeletal muscle in males and females from the GH-transgenic zebrafish (Danio rerio) lineage F0104, comparing the expression of genes related to the somatotrophic axis and myogenesis. Histological analysis demonstrated that transgenic fish presented enhanced muscle hypertrophy when compared to non-transgenic fish, with
\end{abstract}

C. E. da Rosa · L. F. Marins ( $\square)$

Instituto de Ciências Biológicas, Universidade

Federal do Rio Grande, FURG, Avenida Itália,

Km 8, Rio Grande, RS 96201-900, Brazil

e-mail: dqmluf@furg.br

D. V. Almeida · L. F. Marins

Programa de Pós-Graduação em Ciências Fisiológicas, Fisiologia Animal Comparada, Instituto de Ciências

Biológicas, FURG, Rio Grande, Brazil

R. Y. Kuradomi · M. A. Figueiredo · L. F. Marins

Programa de Pós-Graduação em Aqüicultura,

Instituto de Oceanografia, FURG, Rio Grande, Brazil

C. F. C. Lanes

Faculty of Biosciences and Aquaculture,

Bodø University College, 8049 Bodø, Norway

R. Maggioni

Instituto de Ciências do Mar, Universidade

Federal do Ceará, UFC, Fortaleza, CE, Brazil

M. D. P. Silva

Departamento de Morfologia, Instituto de Biociências, Universidade Estadual Paulista, UNESP,

Botucatu, SP, Brazil transgenic females being more hypertrophic than transgenic males. The expression of genes related to muscle growth revealed that transgenic hypertrophy is independent from local induction of insulin-like growth factor 1 gene (igfl). In addition, transgenic males exhibited significant induction of myogenin gene (myog) expression, indicating that myog may mediate hypertrophic growth in zebrafish males overexpressing GH. Induction of the $\alpha$-actin gene (actal) in males, independently from transgenesis, also was observed. There were no significant differences in total protein content from the muscle. Our results show that muscle hypertrophy is independent from muscle igfl, and is likely to be a direct effect of excess circulating GH and/or IGF1 in this transgenic zebrafish lineage.

Keywords Transgenic zebrafish . Growth hormone - Skeletal muscle . Hypertrophy · Myogenic factors

\section{Introduction}

Growth hormone $(\mathrm{GH})$ is a pluripotent vertebrate hormone produced by the hypophysis, with the main role of mediating somatic growth. GH acts by binding with specific transmembrane receptors (GHR) located in the target tissues (Reinecke et al. 2005). This 
interaction triggers an intracellular signalling cascade that culminates with the transcription of specific genes involved in the development of biological responses to GH (Schindler and Darnell 1995; Ihle 1996; Waters et al. 2006). Physiological response to GH is mainly developed and controlled through a chain known as the somatotrophic axis, where insulin-like growth factor 1 (IGF1) is the main mediator (Moriyama et al. 2000; Butler and Le Roith 2001).

IGF1 integrates tissue-specific regulation and many biological events through interaction with specific receptors (IGF1R) which are present in the target cells (Moriyama et al. 2000; Wood et al. 2005). In fishes, as well as in other vertebrates, the liver is the main IGF1 production site (Yakar et al. 1999; Reinecke et al. 2005; Wood et al. 2005). A positive correlation between plasma IGF1 and growth rate has been demonstrated (Kajimura et al. 2001; Uchida et al. 2003). However, igfl gene expression can occur in other tissues, playing both autocrine as well as paracrine roles (for a review, refer to Wood et al. 2005). IGF1 production outside the liver seems to play an important role in growth (Yakar et al. 1999; Butler and Le Roith 2001; Nordgarden et al. 2006; Eppler et al. 2007).

In skeletal muscle, GH can act upon muscle growth independently from IGF1 (Nordgarden et al. 2006; Sotiropoulos et al. 2006). However, IGF1 maintains its role in the formation, upkeep and regeneration of muscle tissue (Stewart and Rotwein 1996; Benito et al. 1996; Le Roith et al. 2001; Rabinovsky et al. 2002), participating in myoblast proliferation, myogenic differentiation and muscle hypertrophy (Czerwinski et al. 1994; Florini et al. 1996; Le Roith et al. 2001). This diversity of roles suggests that IGF1 acts in synergy with $\mathrm{GH}$ in the process of promoting skeletal muscle growth. Skeletal muscle growth in fishes involves the proliferation and differentiation of myogenic cells, also known as adult myoblasts or myosatellite cells, which are responsible for muscle fiber hyperplasic and hypertrophic growth (Koumans and Akster 1995; Johnston 1999; Rowlerson and Veggetti 2001; Johansen and Overturf 2005). Hyperplasia and hypertrophy are regulated by myogenic regulation factors (MRFs) that include myogenic differentiation 1 protein (MYOD1), myogenic factor 4 or myogenin (MYOG), myogenic factor 5 (MYF5), and the MRF4 family (Watabe 1999; Watabe 2001). The MRFs contain a conserved central domain known as the Ebox, which is crucial for DNA sequence recognition, allowing the MRFs to locate a promoter motif that is present in most muscle-specific genes (Lassar et al. 1989; Murre et al. 1989; Blackwell and Weintraub 1990). Muscle growth in both mammals and fishes seems to be controlled by myostatin (MSTN), a protein from the TGF- $\beta$ (transforming growth factor $\beta$ ) family, known as a potent muscle growth mediator (McPherron et al. 1997; Acosta et al. 2005).

Genetic manipulation involving the $g h$ gene often has been used to enhance fish growth rate in aquaculture species in experimental level (Devlin et al. 2006). In most cases, $g h$ overexpression causes a significant increase in growth (Du et al. 1992; Rahman et al. 1998; Nam et al. 2001; Devlin et al. 2004; Figueiredo et al. 2007a, b). However, growth enhancement by GH injection as well as by gene overexpression may alter muscle tissue structure, increasing the relative amount of fibers with smaller diameter, as observed in rainbow trout, coho salmon and Arctic char (Weatherley and Gill 1982; Fauconneau et al. 1997; Hill et al. 2000; Pitkänen et al. 2001).

Even though there are a number of GH-transgenic fish lineages, the relationship among hormone overexpression, muscle tissue structure, and sex-specific expression of genes involved in the somatotrophic axis and myogenesis is rarely approached. A sex-dependent secretory profile has been reported for pituitary GH in mammals (Jansson et al. 1985; Canosa et al. 2007), but this pattern has not been proven for fishes. We recently have developed and presented a genetically modified lineage of the zebrafish Danio rerio, named F0104, which overexpresses a piscine GH gene (Figueiredo et al. 2007a). The F0104 lineage can be used as a model for studies of muscle growth. Different genotypes of this lineage have been studied for growth and growth-related gene expression, including liver igfl expression (Figueiredo et al. 2007b), metabolism and the production of reactive oxygen species (Rosa et al. 2008), and intracellular signalling control mechanisms in the somatotrophic axis (Studzinski et al. 2009). Therefore, the objective of the present study was to approach the relationship between white skeletal muscle morphology and the expression of genes involved in the somatotrophic axis and myogenesis in adult fish from the transgenic lineage F0104, considering the influence of sex. 


\section{Materials and methods}

Transgenic fish

Transgenic and non-transgenic control fish were obtained from crosses between non-transgenic females and hemizygous transgenic males from lineage F0104, following a previously described protocol (Figueiredo et al. 2007a). The F0104 lineage was produced by the co-injection of transgenes $\mathrm{c} \beta \mathrm{A} /$ msGH and $\mathrm{c} \beta \mathrm{A} / \mathrm{GFP}$. Both transgenes include the carp (Cyprinus carpio) $\beta$-actin promoter and either marine silverside (Odontesthes argentinensis) GH cDNA (Marins et al. 2002) or the green fluorescent protein (GFP) gene. GFP was used as a marker for successful gene transfer, allowing identification through fluorescence analysis (excitation $=485 \mathrm{~nm}$; emission $=520 \mathrm{~nm}$ ).

Growth experiments

All fish were reared for 7 months in a system equipped with biological filtration. Each group (transgenic females-TF; transgenic males-TM, non-transgenic females-NTF and non-transgenic males-NTM) was kept at an average density of one fish per litre of water. Water quality was monitored at least once a week. Temperature, $\mathrm{pH}$, nitrogen compounds and photoperiod were kept at the recommended optimum levels for zebrafish (Westerfield 1995). Fish were fed a commercial feed with a high level of total protein $(47.5 \%)$ twice a day, ad libidum. At the end of the experiment, the animals were anesthetised (Tricaine methosulphonate, $0.1 \mathrm{mg} \mathrm{mL}^{-1}$ ) and photographed with a digital camera. Standard length $\left(L_{\mathrm{s}}\right)$ was taken from each image through the open source software IMAGE J (US National Institute of Health, available at http://rsb. info.nih.gov/ij/).

RNA extraction and cDNA synthesis

Total RNA was isolated from white muscle of six individuals from each group, using TRI Reagent Solution (Applied Biosystems, Brazil), following the manufacturer's recommendations. Total RNA was treated with the RNAse-free DNAse I kit (Applied Biosystems, Brazil), and quantified through a Qubit fluorimeter (Invitrogen, Brazil) using Quant-iT RNA Assay kit (Invitrogen, Brazil). RNA integrity was assessed through electrophoresis on $1 \%$ agarose gels. cDNA was synthesised using a High Capacity cDNA Reverse Transcription kit (Applied Biosystems, Brazil), following the manufacturer's instructions.

\section{Gene expression}

Gene expression was analysed quantitatively through quantitative Real Time PCR (qRT-PCR). Each sample $(n=4)$ was analysed in triplicate. Gene-specific primers (Table 1) were designed using the software Primer Express 2.0 (Applied Biosystems, Brazil) from sequences available at GenBank. qRT-PCR reactions were performed in a 7,300 Real-Time PCR System (Applied Biosystems, Brazil) using a SYBR green PCR Master Mix kit (Applied Biosystems, Brazil). One-tenth of the cDNA was used for each $20 \mu \mathrm{L}$ reaction. qRT-PCRs with cDNA serial dilutions were performed for all primers, in order to test reaction efficiency. qRT-PCR conditions were $50^{\circ} \mathrm{C} / 3 \mathrm{~min}$, $95^{\circ} \mathrm{C} / 10 \mathrm{~min}$, then 40 cycles of $95^{\circ} \mathrm{C} / 15 \mathrm{~s}$ and $60^{\circ} \mathrm{C} /$ $1 \mathrm{~min}$. The dissociation curve was performed at $95^{\circ} \mathrm{C} /$ $15 \mathrm{~s}, 60^{\circ} \mathrm{C} / 1 \mathrm{~min}$ and $95^{\circ} \mathrm{C} / 15 \mathrm{~s}$. The expression of target genes (growth hormone receptor a-ghra; insulin-like growth factor $1-i g f 1$; myogenic differentiation 1-myod $;$; myogenin - myog; myostatin $\mathrm{b}-$ $m s t n b$; eukaryotic translation initiation factor 2 , subunit 2 beta-eif $2 s 2$, myosin heavy chain 4-myhc4 and $\alpha$-actin-actal) was normalized to that of the elongation factor 1 alpha gene (efla), which did not show significant differences among experimental groups (data not shown).

Total protein quantification

In order to quantify total proteins, six muscle tissue samples from each group were weighed (12 mg each) and homogenised in a $1 \mathrm{mg}: 9 \mu \mathrm{L}$ mixture of tissue:buffer (Tris-HCl $100 \mathrm{mM}$; EDTA $2 \mathrm{mM}$; $\mathrm{MgCl}_{2}+6 \mathrm{H}_{2} \mathrm{O} 5 \mathrm{mM}$, pH 7.75). Homogenised sam-

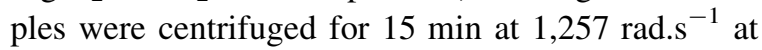
$4^{\circ} \mathrm{C}$ and the supernatant kept on ice. A $1-\mu \mathrm{L}$ aliquot was used to measure the amount of total protein on a Qubit fluorimeter (Invitrogen, Brazil) using a QuantiT Protein Assay kit (Invitrogen, Brazil), following the manufacturer's recommendations. The resulting values were normalised by sample weight and used in the following analysis as milligrams of protein per gram of muscle tissue $\left(\mathrm{mg} \mathrm{g}^{-1}\right)$. 
Table 1 qRT-PCR gene-specific primers designed using sequences available at GenBank (www.ncbi.nlm.nih.gov)

\begin{tabular}{|c|c|c|c|}
\hline Gene & Forward primer & Reverse primer & GenBank \\
\hline efla & 5'-CAAAATTGGAGGTATTGGAACTGTAC-3' & 5'-TCAACAGACTTGACCTCAGTGGTT-3' & L47669 \\
\hline ghra & 5'-TGCTGTGCGCTACAAAATGG- $3^{\prime}$ & 5'-GCTTCTGCAAAGGCTGATAGAAA-3' & BC134903 \\
\hline igf1 & 5'-ACTTTGTGGGCACATGCAAA- $3^{\prime}$ & 5'-CATGATCTCATTGCGAATTCCTT-3' & BC114262 \\
\hline myod1 & 5'-GGAGCGAATTTCCACAGAGACT-3' & 5'-GTGCCCCTCCGGTACTGA-3' & BC114261 \\
\hline myog & 5'-GGCCGCTACCTTGAGAGAGA-3' & 5'-GAGCCTCAAAGGCCTCGTT-3' & AF202639 \\
\hline mstnb & 5'-TGCTTTCCGCAAGACACTGT-3' & 5'-GAAGCGGTGCCCAGAGAGT-3' & AF540956 \\
\hline eif $2 s 2$ & 5'-GCGCTCGTGGGTTTGTTG-3' & 5'-CCTCAGGCTTTCGGTTTCC-3' & BC066706 \\
\hline myhc4 & 5'-GCGCGCTGACATTTCTGA-3' & 5'-CAGCGTCACGGCTTTTGG-3' & AY921650 \\
\hline actal & 5'-TCTGTCCACCTTCCAGCAGAT-3' & 5'-GATGGACCTGCCTCGTCGTA-3' & AF180887 \\
\hline
\end{tabular}

Histological analysis

Six adult zebrafish per treatment at 7 months of age were anesthetised (Tricaine methosulfonate, $0.1 \mathrm{mg} \mathrm{mL}^{-1}$ ) and euthanized on ice for collection of tissue samples. Samples were immediately fixed in Karnovsky solution (2.5\% glutaraldehyde, $2 \%$ paraformaldehyde, $0.1 \mathrm{M}$ phosphate buffer, $\mathrm{pH}$ 7.2) and preserved in $70 \%$ ethanol. Tissue samples then were dehydrated in an ethanol series (80, 95 and 100\%) and embedded in resin (Historesin-Leica Instruments $\mathrm{GmbH}$, Germany), according to the manufacturer's recommendations. Transverse histological sections $(2 \mu \mathrm{m})$ from muscle fibers were obtained with a glass blade microtome. The sections were stained by hematoxilin-eosin (HE). Permanent slides were observed under an optical microscope $(400 \times)$ equipped with a digital camera. From the images, the minor diameter was measured for at least 100 white muscle fibers per animal. All measures were taken using the open source software IMAGE J (US National Institute of Health, available at http://rsb.info.nih.gov/ij/).

Statistical analysis

Student's $t$ test was used to compare average values of standard length $\left(L_{\mathrm{S}}\right)$ and total protein content $\left(P_{\mathrm{T}}\right)$ between transgenic and non-transgenic fish. Analysis of variance (ANOVA) was used to compare groups TF, TM, NTF and NTM, following Tukey's HSD test at a 5\% significance level (Sokal and Rohlf 1995). Variance of muscle fiber proportions was analysed through a $r \times c$ table at a 5\% significance level. When a significant difference was found, Marascuillo's method for multiple proportions comparison was applied (National Institute of Statistics-NIST, http://www.itl.nist.gov/div898/handbook). For gene expression analysis, the relative quantification method from the REST software (Pfaffl et al. 2002) was used, making pairwise comparisons among $\mathrm{T} \times \mathrm{NT}, \mathrm{TF} \times \mathrm{NTF}, \mathrm{TM} \times \mathrm{NTM}, \mathrm{TM} \times \mathrm{TF}$ and $\mathrm{NTM} \times \mathrm{NTF}$. The reference sample in each pairwise comparison was either the non-transgenic or the female.

\section{Results}

In the present study, transgenic fish were longer ( $\left.L_{\mathrm{s}}=3.40 \pm 0.35 \mathrm{~cm} ; n=20\right)$ than the non-transgenic fish $\left(L_{\mathrm{s}}=2.82 \pm 0.19 \mathrm{~cm} ; n=20\right)$. Comparing sexes within the same group, TF $\left(L_{\mathrm{s}}=3.56 \pm\right.$ $0.32 \mathrm{~cm} ; n=10$ ) were significantly longer than TM $\left(L_{\mathrm{s}}=3.22 \pm 0.30 \mathrm{~cm} ; n=10\right)$. However, among non-transgenic fish, lengths of NTF $\left(L_{\mathrm{s}}=2.93 \pm\right.$ $0.18 \mathrm{~cm} ; n=10$ ) were not significantly different from those of NTM $\left(L_{\mathrm{s}}=2.72 \pm 0.13 \mathrm{~cm} ; n=10\right)$. Comparing animals of the same sex, TM and TF were significantly longer than NTM and NTF, respectively.

In the muscle fiber analysis, the diameter frequency distributions revealed profiles that were significantly different between transgenic and nontransgenic fish (Fig. 1). The largest difference among the groups was observed regarding $40 \mu \mathrm{m}$ diameter fibers (Fig. 1). In the present study, fibers at or below $40 \mu \mathrm{m}$ diameter were called "thin" fibers, while fibers above this value were called "thick" fibers. Figure 2 shows that the relative proportion of thick fibers was significantly higher in transgenic (75\%) than non-transgenic fish (39\%). Comparing sexes 


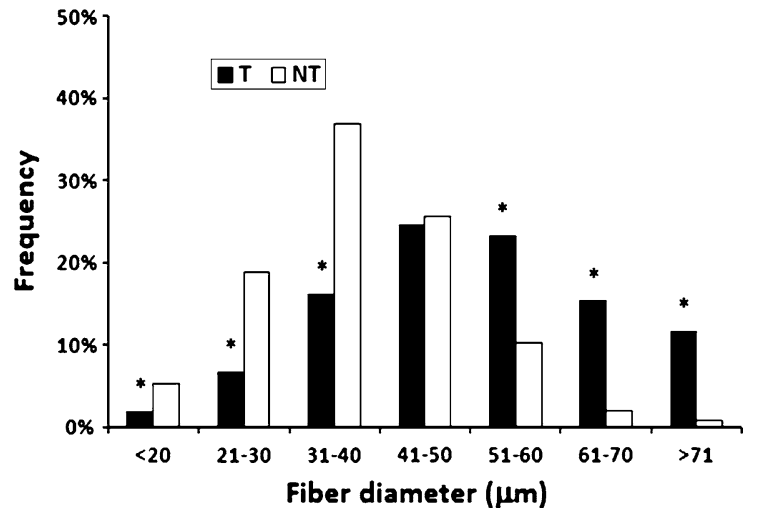

Fig. 1 Frequency distribution of muscle fiber diameters from transgenic $(T)$ and non transgenic (NT) zebrafish (Danio rerio). Asterisks represent statistically significant differences $(P<0.05)$

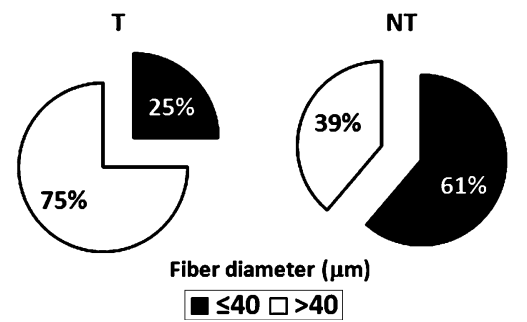

Fig. 2 Proportion of thin $(\leq 40 \mu \mathrm{m})$ and thick $(>40 \mu \mathrm{m})$ muscle fibers from transgenic $(T)$ and non transgenic (NT) zebrafish (Danio rerio). Differences were significantly different at $P<0.05$

(Fig. 3), the diameter frequency distribution was not different between NTM and NTF, but the difference was significant for TM and TF. The proportion of thick and thin fibers was similar among non-transgenic fish, while TF fish presented a significantly higher $(P<0.05)$ proportion of thick fibers than TM fish (Fig. 4). Both TM and TF fish showed a significant increase in thick fiber proportion than NTM and NTF, respectively (Fig. 4).

In the gene expression analysis, a significant $(P<0.05) 60 \%$ increase in myog expression was observed among transgenic fish (Fig. 5). Among nontransgenic fish, only actal showed higher induction in males $(133 \%)$ than in females (Fig. 6a). For TM fish, higher expression of actal (47\%) as well as myog (53\%) was observed, in comparison to TF fish (Fig. 6b). When comparing females, no significant differences were observed in the expression of the analysed genes (Fig. 7a). Among males, however, myog was found at a significantly higher level (124\%)

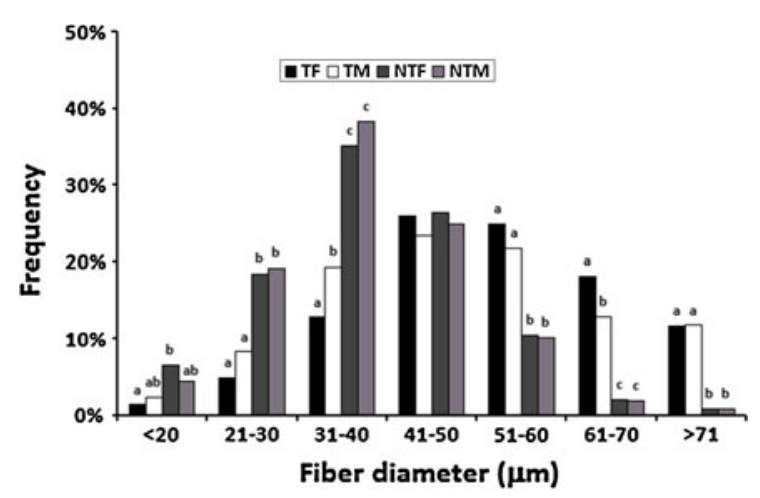

Fig. 3 Frequency distribution of muscle fiber diameters from transgenic and non transgenic zebrafish (Danio rerio), considering sex. $T F$ transgenic females; $T M$ transgenic males; NTF non transgenic females; NTM non transgenic females. Different letters represent statistically significant differences $(P<0.05)$

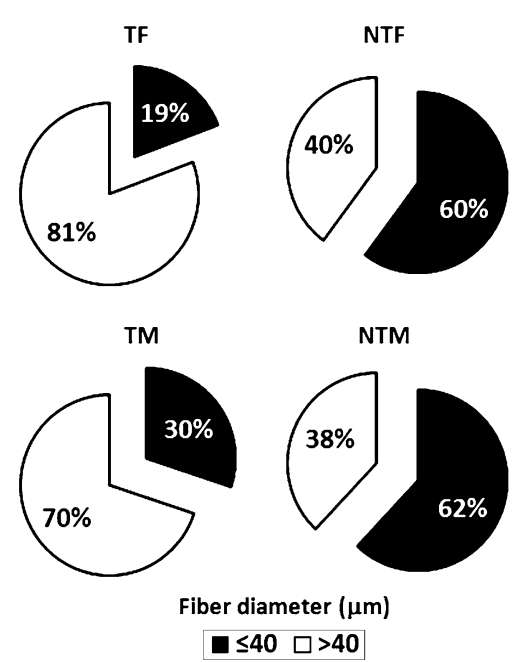

Fig. 4 Proportion of thin $(\leq 40 \mu \mathrm{m})$ and thick $(>40 \mu \mathrm{m})$ muscle fibers from transgenic $(T)$ and non transgenic (NT) zebrafish (Danio rerio), considering sex. $T F$ transgenic females; TM transgenic males; NTF non transgenic females; $N T M$ non transgenic females. Differences were significantly different at $P<0.05$

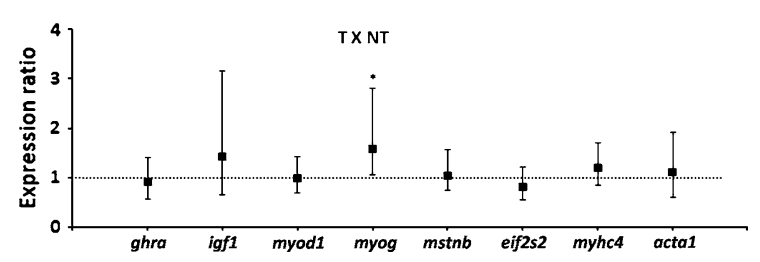

Fig. 5 Relative gene expression comparing transgenic $(T)$ and non transgenic (NT) zebrafish (Danio rerio). NT were considered controls, where gene expression $=1$ (dashed line). Asterisks represent statistically significant differences $(P<0.05)$ 

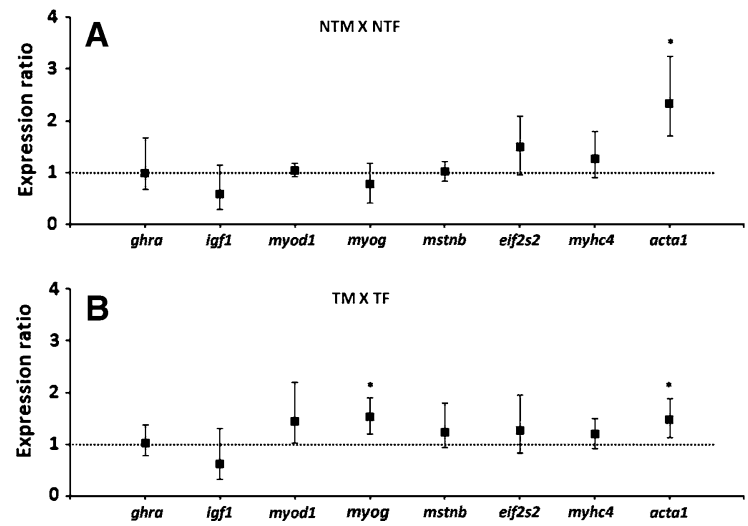

Fig. 6 Relative gene expression comparing zebrafish (Danio rerio) males and females, considering transgenesis (transgenic and non transgenic). a Comparison between non transgenic males $(N T)$ and females $(N T F)$. b Comparison between transgenic males $(T M)$ and females $(T F)$. In all comparisons females were considered controls, where gene expression $=1$ (dashed line). Asterisks represent statistically significant differences $(P<0.05)$
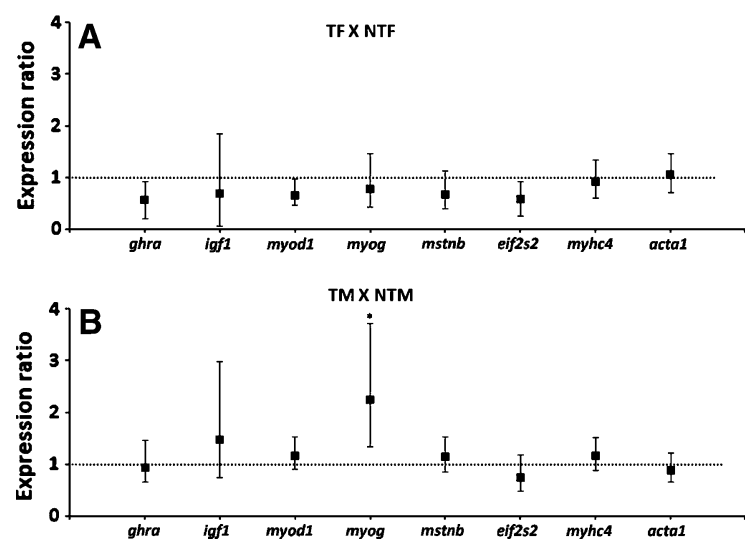

Fig. 7 Relative gene expression comparing transgenic and non transgenic zebrafish (Danio rerio), considering sex. a Comparison between transgenic females $(T F)$ and non transgenic females $(N T F)$. b Comparison between transgenic males $(T M)$ and non transgenic males (NTM). In all comparisons non transgenics were considered controls, where gene expression $=1$ (dashed line). Asterisks represent statistically significant differences $(P<0.05)$

in TM fish (Fig. 7b). No significant difference in total protein content was observed between transgenic and non-transgenic fish or between males and females.

\section{Discussion}

Myogenesis involves a series of processes which culminate with the development and growth of muscle tissue. Among mammals, post-natal muscle growth occurs mainly through hypertrophy (increase in myotube size) and very little through hyperplasia (increase in myotube numbers and cellular proliferation). However, in most fish species, muscle growth by both hypertrophy and hyperplasia are observed during the whole life cycle (Rowlerson and Veggetti 2001). Among species that present limited muscle growth, such as zebrafish, this process involves a short hyperplastic growth period at the early development stages, followed by hypertrophy of the fibers formed (Weatherley et al. 1988). Considering that transgenic mice overexpressing $g h$ show a marked hypertrophy (Dudley and Portanova 1987; Hikida et al. 1995; Clark et al. 2006), mainly hypertrophic muscle growth could be predicted for GH-transgenic zebrafish. Indeed, the present study showed a change in the muscle fiber diameter distribution in $\mathrm{GH}$ transgenic zebrafish (Fig. 1). The transgenic profile was characterized by a $36 \%$ higher frequency of thick fibers $(>40 \mu \mathrm{m})$ (Fig. 2). It is possible that these differences are related to the fusion of myoblasts to pre-existing fibers, which characterizes hypertrophy (Valente et al. 1999; Rowlerson and Veggetti 2001).

Considering that $\mathrm{GH}$ excess in transgenic adult zebrafish from lineage F0104 triggers hepatic igfl transcription (Figueiredo et al. 2007b), in association with the muscle hypertrophy reported in the present study, a new question arises: is increased muscle growth an effect from $\mathrm{GH}$ directly, from hepatic IGF1, or from both? In order to approach this question, ghra and igfl expression were measured, comparing transgenic and non-transgenic fish (Fig. 5). The results clearly show that GH excess is not associated with increased transcription for either ghra or igfl in transgenic zebrafish muscle. Sotiropoulos et al. (2006) provided evidence that GH has a hypertrophic effect on muscle, stimulating myoblast fusion into mammalian myotubes, suggesting that GH and IGF1 present independent and additive hypertrophic effects through distinct signalling pathways. Since IGF1 is considered a critical myogenic agent (Florini et al. 1996; Shavlakadze et al. 2005), the lack of muscle igfl induction in transgenic zebrafish observed here may indicate that circulating IGF1 is already at a high level. Even though liver igfl was not evaluated in the present study, Figueiredo et al. (2007b) already reported its induction in the same zebrafish model. 
The expression analysis of other myogenesis regulation factors (myod, myog and mstnb) showed that only myog was significantly induced among transgenics (Fig. 5). Many studies have demonstrated that myogenin is involved in the control of myotube fusion and growth (Hasty et al. 1993; Nabeshima et al. 1993; Black and Olson 1998; Pownall et al. 2002), and that this transcription factor is likely to be a hypertrophy indicator (Johansen and Overturf 2005). The increased myog expression observed here among transgenic fish represents further evidence of its role in support of hypertrophy. However, a significant increase in myog expression was observed only among transgenic males. It is possible that hypertrophic females had reached their growth limit before the time of sampling. The largest standard length recorded for wild zebrafish is $3.5 \mathrm{~cm}$ (Spence et al. 2007). Transgenic females in the present study averaged $3.56( \pm 0.32) \mathrm{cm}$ standard length, with hypertrophy significantly higher than males. Even though these data suggest that females had reached the maximum size, this hypothesis remains to be tested.

The analysis of actal showed sex-dependent expression which is independent of transgenic status. In this case, males from both groups showed higher expression levels than females. Recent studies on mammals suggested the involvement of androgenic hormones and their receptors with the promoter region of the ACTA1 gene, affecting its expression (Vlahopoulos et al. 2005; Hong et al. 2008). It is well known that ACTA1 in is an important skeletal muscle protein, and that the androgens are likely to produce an anabolic effect through increased expression (Hong et al. 2008). This is the first time that differential sex-specific actal expression is reported for fish muscle tissue.

No differences were found in the total protein content between transgenic and non-transgenic fish or between males and females from both groups. Even though actal expression clearly was induced in males from both groups, this induction does not seem enough to provoke a significant increase in total muscle protein content. This result, however, is consistent with unaltered eif $2 s 2$ expression, since this gene is an indicator of general protein synthesis, recycling other initiation factors (Price et al. 1996). Studies on GH-transgenic common carp have reported a higher level of total protein among transgenics (Chatakondi et al. 1995; Fu et al. 1998;
Dunham et al. 2002). However, lower total protein levels have been recorded for transgenic Atlantic salmon (Cook et al. 2000) and Nile tilapia (Rahman et al. 2001). Hence, the effect of GH on total protein levels seems to vary across species and transgenic lines.

The results presented here showed that $\mathrm{GH}$ transgenic zebrafish reach a more hypertrophic muscle structure than non-transgenic fish at the same age. This structure likely resulted from direct $\mathrm{GH}$ action in association with circulating hepatic IGF1. Muscle hypertrophy is likely to be mediated to some extent by myogenin as well. Even though commercial transgenic species, such as salmonids, present hyperplasic growth (Hill et al. 2000; Pitkänen et al. 2001), in the present study, only hypertrophic growth was observed among transgenic zebrafish.

Acknowledgments This work was supported by Brazilian CNPq (Conselho Nacional de Desenvolvimento Científico e Tecnológico) and CAPES (Coordenação de Aperfeiçoamento de Pessoal de Nível Superior).

\section{References}

Acosta J, Carpio Y, Borroto I, González O, Estrada MP (2005) Myostatin gene silenced by RNAi show a zebrafish giant phenotype. J Biotechnol 119:324-331

Benito M, Valverde AM, Lorenzo M (1996) IGF-I: A mitogen also involved in differentiation processes in mammalian cells. Int J Biochem Cell Biol 28:499-510

Black BL, Olson EN (1998) Transcriptional control of muscle development by myocyte enhancer factor-2 (MEF2) proteins. Ann Rev Cell Dev Biol 14:167-196

Blackwell T, Weintraub H (1990) Differences and similarities in DNA-binding preferences of $M y o D$ and $E 2 A$ protein complexes revealed by binding site selection. Science 250:1104-1110

Butler AA, Le Roith D (2001) Control of growth by the somatotropic axis: growth hormone and the insulin-like growth factors have related and independent roles. Ann Rev Physiol 63:141-164

Canosa L, Chang JP, Peter RE (2007) Neuroendocrine control of growth hormone in fish. Gen Comp Endocrinol 151:1-26

Chatakondi N, Lovell RT, Duncan PL, Hayat M, Chen TT, Powers DA, Weete JD, Cummins K, Dunham RA (1995) Body composition of transgenic common carp, Cyprinus carpio, containing rainbow trout growth hormone gene. Aquaculture 138:99-109

Clark RP, Schuenke M, Keeton SM, Staron RS, Kopchick JJ (2006) Effects of growth hormone and insulin-like growth factor I on muscle in mouse models of human growth disorders. Horm Res 66:26-34 
Cook JT, McNiven MA, Richardson GF, Sutterlin AM (2000) Growth rate, body composition and feed digestibility/ conversion of growth enhanced Atlantic salmon (Salmo salar). Aquaculture 188:15-32

Czerwinski SM, Martin JM, Bechtel PJ (1994) Modulation of IGF mRNA abundance during stretch-induced skeletal muscle hypertrophy and regression. J Appl Physiol 76:2026-2030

Devlin RH, Biagi CA, Yesaki TY (2004) Growth, viability and genetic characteristics of $\mathrm{GH}$ transgenic coho salmon strains. Aquaculture 236:607-632

Devlin RH, Sundström LF, Muir WM (2006) Interface of biotechnology and ecology for environmental risk assessments of transgenic fish. Trends Biotechnol 24:89-97

Du SJ, Gong ZY, Fletcher GL, Shears MA, King MJ, Idler DR, Hew CL (1992) Growth enhancement in transgenic Atlantic salmon by the use of an "all-fish" chimeric growth hormone gene construct. Biotechnology (N.Y.) 10:176-181

Dudley GA, Portanova R (1987) Histochemical characteristics of soleus muscle in hGH transgenic mice. Proc Soc Exp Biol Med 185:403-408

Dunham RA, Chatakondi N, Nichols AJ, Kucuktas H, Chen TT, Powers DA, Weete JD, Cummins K, Lovell RT (2002) Effect of rainbow trout growth hormone complementary DNA on body shape, carcass yield, and carcass composition of $\mathrm{F}_{1}$ and $\mathrm{F}_{2}$ transgenic common carp (Cyprinus carpio). Mar Biotechnol 4:604-611

Eppler E, Caelers A, Shved N, Hwang G, Rahman AM, Maclean N, Zapf J, Reinecke M (2007) Insulin-like growth factor I (IGF-I) in a growth-enhanced transgenic (GHoverexpressing) bony fish, the tilapia (Oreochromis niloticus): indication for a higher impact of autocrine/paracrine than of endocrine IGF-I. Transgenic Res 16:479-489

Fauconneau B, Andre S, Chmaitilly J, Le Bail P, Krieg F, Kaushik SJ (1997) Control of skeletal muscle fibers and adipose cell size in the flesh of rainbow trout. J Fish Biol 50:296-314

Figueiredo MA, Lanes CFC, Almeida DV, Marins LF (2007a) Improving the production of transgenic fish germlines: in vivo evaluation of mosaicism in zebrafish (Danio rerio) using a green fluorescent protein (GFP) and growth hormone cDNA transgene co-injection strategy. Genet Mol Biol 30:31-36

Figueiredo MA, Lanes CFC, Almeida DV, Proietti MC, Marins LF (2007b) The effect of GH overexpression on GHR and IGF-I gene regulation in different genotypes of GHtransgenic zebrafish. Comp Biochem Phys D 2:228-233

Florini JR, Ewton DZ, Coolican SA (1996) Growth hormone and the insulin-like growth factor system in myogenesis. Endocr Rev 17:481-517

Fu C, Cu Y, Hung SSO, Zhu Z (1998) Growth and feed utilization by $\mathrm{F}_{4}$ human growth hormone transgenic carp fed diets with different protein levels. J Fish Biol 53:115-129

Hasty P, Bradley A, Morris JH, Edmondson DG, Venuti JM, Olson EN, Klein WH (1993) Muscle deficiency and neonatal death in mice with a targeted mutation in the myogenin gene. Nature 364:501-506

Hikida RS, Knapp JR, Chen WY, Gozdanovic JA, Kopchick JJ (1995) Effects of bovine growth hormone analogs on mouse skeletal muscle structure. Growth Dev Aging 59:121-128
Hill JA, Kiessling A, Devlin RH (2000) Coho salmon (Oncorhynchus kisutch) transgenic for a growth hormone gene construct exhibit increased rates of muscle hyperplasia and detectable levels of differential gene expression. Can J Fish Aquat Sci 57:939-950

Hong $\mathrm{MH}$, Sun $\mathrm{H}$, Jin $\mathrm{CH}$, Chapman $\mathrm{M}$, Hu J, Chang W, Burnett K, Rosen J, Negro-Vilar A, Miner JN (2008) Cellspecific activation of the human skeletal $\alpha$-actin by androgens. Endocrinology 149:1103-1112

Ihle JN (1996) STATs: Signal transducers and activators of transcription. Cell 84:331-334

Jansson JO, Edén S, Isaksson O (1985) Sexual dimorphism in the control of growth hormone secretion. Endocr Rev 6:128-150

Johansen KA, Overturf K (2005) Quantitative expression analysis of genes affecting muscle growth during development of rainbow trout (Oncorhynchus mykiss). Mar Biotechnol 7:576-587

Johnston IA (1999) Muscle development and growth: potential implication for flesh quality in fish. Aquaculture 177:99-115

Kajimura S, Uchida K, Yada T, Riley LG, Byatt JC, Collier RJ, Ainda K, Hirano T, Grau EG (2001) Stimulation of insulinlike growth factor-I production by recombinant bovine growth hormone in Mozambique tilapia, Oreochromis mossambicus. Fish Physiol Biochem 25:221-230

Koumans JTM, Akster HA (1995) Myogenic cells in development and growth of fish. Comp Biochem Phys A 110: 3-20

Lassar A, Buskin JN, Lockshon D, Davis RL, Apone S, Hauschka SD, Weintraub H (1989) $M y o D$ is a sequencespecific DNA binding protein requiring a region of $m y c$ homology to bind to the muscle creatine kinase enhancer. Cell 58:823-831

Le Roith D, Scavo L, Buttle A (2001) What is the role of circulating IGF-I? Trends Endocrinol Metab 12:48-52

Marins LF, Iyengar A, Maclean N, Levy JA, Sohm F (2002) Simultaneous overexpression of $G H$ and STAT5b genes inhibits the STAT5 signalling pathway in tilapia (Oreochromis niloticus) embryos. Genet Mol Biol 23:293-298

McPherron AC, Lawler AM, Lee SJ (1997) Regulation of skeletal muscle mass in mice by a new TGF- $\beta$ superfamily member. Nature 387:83-90

Moriyama S, Ayson FG, Kawauchi H (2000) Growth regulation by insulin-like growth factor-I in fish. Biosci Biotech Bioch 64:1553-1562

Murre C, McCaw PS, Vaessin H, Caudy M, Jan LY, Jan YN, Cabrera CV, Buskin JN, Hauschka SD, Lassar AB (1989) Interactions between heterologous helix-loop-helix proteins generate complexes that bind specifically to a common DNA sequence. Cell 58:537-544

Nabeshima Y, Hanaoka K, Hayasaka M, Esumi E, Li S, Nonaka I, Nabeshima Y (1993) Myogenin gene disruption results in perinatal lethality because of severe muscle defect. Nature 364:532-535

Nam YK, Noh JK, Cho YS, Cho HJ, Cho KN, Kim CG, Kim DS (2001) Dramatically accelerated growth and extraordinary gigantism of transgenic mud loach Misgurnus mizolepis. Transgenic Res 10:353-362

Nordgarden U, Fjelldal PG, Hansen T, Björnsson BT, Wargelius A (2006) Growth hormone and insulin-like growth 
factor-I act together and independently when regulating growth in vertebral and muscle tissue of atlantic salmon postsmolts. Gen Comp Endocrinol 149:253-260

Pfaffl MW, Horgan GW, Dempfle L (2002) Relative expression software tool $\left(\mathrm{REST}^{\odot}\right)$ for group-wise comparison and statistical analysis of relative expression results in real-time PCR. Nucleic Acids Res 30:e36

Pitkänen TI, Xie SQ, Krasnov A, Mason PS, Mölsä H, Stickland NC (2001) Changes in tissue cellularity are associated with growth enhancement in genetically modified Arctic char (Salvelinus alpinus L.) carrying recombinant growth hormone gene. Mar Biotechnol 3:188-197

Pownall ME, Gustafsson MK, Emerson CP (2002) Myogenic regulatory factors and the specification of muscle progenitors in vertebrate embryos. Ann Rev Cell Dev Biol 18:747-783

Price NT, Kimball SR, Jefferson LS, Proud CG (1996) Cloning of cDNA for the gamma-subunit of mammalian translation initiation factor $2 \mathrm{~B}$, the guanine nucleotide-exchange factor for eukaryotic initiation factor 2. Biochem $\mathrm{J}$ 318:631-636

Rabinovsky ED, Gelir E, Gelir S, Lui H, Kattash M, Demayo FJ, Shenaq SM, Schwartz RJ (2002) Targeted expression of IGF-1 transgene to skeletal muscle accelerates muscle and motor neuron regeneration. FASEB J 17:53-55

Rahman MA, Mak R, Ayad H, Smith A, Maclean N (1998) Expression of a novel piscine growth hormone gene results in growth enhancement in transgenic tilapia (Oreochromis niloticus). Transgenic Res 7:357-369

Rahman MA, Ronyai A, Engidaw BZ, Jauncey K, Hwang GL, Smith A, Roderick E, Penman D, Varadi L, Maclean N (2001) Growth and nutritional trials on transgenic Nile tilapia containing an exogenous fish growth hormone gene. J Fish Biol 59:62-78

Reinecke M, Björnsson BT, Dickhoff WW, McCormick SD, Navarro I, Power DM, Gutiérrez J (2005) Growth hormone and insulin-like growth factors in fish: where we are and where to go. Gen Comp Endocrinol 42:20-24

Rosa CE, Figueiredo MA, Lanes CFC, Almeida DV, Monserrat JM, Marins LF (2008) Metabolic rate and reactive oxygen species production in different genotypes of GH-transgenic zebrafish. Comp Biochem Phys B 149:209-214

Rowlerson A, Veggetti A (2001) Cellular mechanisms of postembryonic muscle growth in aquaculture species. In: Johnston IA (ed) Muscle development and growth. Academic Press, London, pp 103-140

Schindler C, Darnell JE (1995) Transcriptional responses to polypeptide ligands: the JAK-STAT pathway. Ann Rev Biochem 64:621-651

Shavlakadze T, Winn N, Rosenthal N, Grounds MD (2005) Reconciling data from transgenic mice that overexpress IGF-I specifically in skeletal muscle. Growth Horm IGF Res 15:4-18

Sokal RR, Rohlf FJ (1995) Biometry, 3rd edn. WH Freeman, New York
Sotiropoulos A, Ohanna M, Kedzia C, Menon RK, Kopchick JJ, Kelly PA, Pende M (2006) Growth hormone promotes skeletal muscle cell fusion independent of insulin-like growth factor 1 up-regulation. Proc Natl Acad Sci USA 103:7315-7320

Spence R, Fatema MK, Ellis S, Ahmed ZF, Smith C (2007) The diet, growth and recruitment of wild zebrafish (Danio rerio) in Bangladesh. J Fish Biol 71:304-309

Stewart CE, Rotwein P (1996) Growth, differentiation, and survival: multiple physiological functions for insulin-like growth factors. Physiol Rev 76:1005-1026

Studzinski AL, Almeida DV, Lanes CF, Figueiredo MA, Marins LF (2009) SOCS1 and SOCS3 are the main negative modulators of the somatotrophic axis in liver of homozygous GH-transgenic zebrafish (Danio rerio). Gen Comp Endocrinol 161:67-72

Uchida K, Kajimura S, Riley LG, Hirano T, Ainda K, Grau EG (2003) Effects of fasting on growth hormone/insulin-like growth factor I axis in the tilapia, Oreochromis mossambicus. Comp Biochem Phys A 134:429-433

Valente LMP, Rocha E, Gomes EFS, Silva MW, Oliveira MH, Monteiro RAF, Fauconneau B (1999) Growth dynamics of white and red muscle fibers in fast and slow-growing strains of rainbow trout. J Fish Biol 55:675-691

Vlahopoulos S, Zimmer WE, Jenster G, Belaguli NS, Balk SP, Brinkmann AO, Lanz RB, Zoumpourlis VC, Schwartz RJ (2005) Recruitment of the androgen receptor via serum response factor facilitates expression of a myogenic gene. J Biol Chem 280:7786-7792

Watabe S (1999) Myogenic regulatory factors and muscle differentiation during ontogeny in fish. J Fish Biol 55:1-18

Watabe S (2001) Myogenic regulatory factors. In: Johnston IA (ed) Muscle development and growth. Academic Press, London, pp 19-41

Waters MJ, Hoang HN, Fairlie DP, Pelekanos RA, Brown RJ (2006) New insights into growth hormone action. J Mol Endocrinol 36:1-7

Weatherley AH, Gill H (1982) Influence of bovine growth hormone on the growth dynamics of mosaic muscle in relation to somatic growth of rainbow trout $O$. mykiss. J Fish Biol 20:165-172

Weatherley A, Gill H, Lobo AF (1988) Recruitment and maximal diameter of axial muscle fibers in the teleosts and their relationship to somatic growth and ultimate size. J Fish Biol 33:851-859

Westerfield M (1995) The zebrafish book: a guide for the laboratory use of zebrafish Danio rerio, 3rd edn. University of Oregon Press, Eugene

Wood AW, Duan C, Bern HA (2005) Insulin-like growth factor signaling in fish. Int Rev Cytol 243:215-285

Yakar S, Liu J, Stannard B, Butler A, Accili D, Sauer B, Le Roith D (1999) Normal growth and development in the absence of hepatic insulin-like growth factor I. Proc Natl Acad Sci USA 96:7324-7329 